\title{
Why Infants Rarely Die of COVID-19 and Morbidity and Mortality Rates Vary by Location: Pneumococcal and Hib Vaccinations as Possible Means to Mitigate Future Pandemics
}

\author{
Robert Root-Bernstein, Ph. D., Professor of Physiology, Michigan State University, East Lansing, MI \\ 48824 USA; rootbern@msu.edu
}

\section{ABSTRACT}

Two conundrums have puzzled COVID-19 investigators: 1) morbidity and mortality is rare among Infants and young children and 2) rates of morbidity and mortality exhibit very large variances across nations, locals and even within cities. These differences correlate with rates of Haemophilus influenzae type $\mathrm{B}(\mathrm{Hib})$ and pneumococcal vaccination, which are almost universal among infants and vary widely by geography among adults and the elderly. The higher the rate of vaccination, the lower the COVID-19 morbidity and mortality. Vaccination rates with other vaccines, including BCG and poliovirus, do not correlate with COVID-19 risks. Notably, both Hib and pneumoccoci are common co-infections with influenza and coronaviruses and are associated with more severe disease and risk of death. Whether the vaccines simply protect against COVID-19 complications, directly protect against COVID-19 infection by inducing cross-reactive immunity, or are markers for some other types of protection such as availability of better healthcare, is not yet known. What is known is that improving coverage rates of Hib and pneumococcal vaccination has significantly lowered severe morbidity and mortality in influenza epidemics and might have similar efficacy for mitigating coronavirus outbreaks. If infants and children are valid indicators, the beneficial effects might be very significant. The possibility that anti-viral proteins in milk (e.g., lactoferrin) protect against COVID-19 is also explored.

\section{PROBLEM AND HYPOTHESIS}

Why do infants and young children rarely develop serious COVID-19 infections and almost never die of it? Why are there huge differences in the incidence of severe COVID-19 cases and deaths from one nation to another? I hypothesize that one controlling factor is the rate of vaccination against Haemophilus influenzae type B and pneumococcal infections by Streptococcus pneumoniae, which are the most common causes of lower respiratory tract infections and fatalities following viral infections such as influenza and coronaviruses (leven, et al., 2018; Root-Bernstein, et al., 2013; Morens, et al., 2008; McNamee and Harmsen, 2006; Brundage, 2006). Additionally, antiviral milk proteins such as antibodies, casein and lactoferrin may protect pre-vaccinated infants (Sun \& Jenssen, 2012).

\section{EVIDENCE FOR THE HYPOTHESIS}

Various types of existing evidence support the hypothesis. First, infants and young children rarely develop serious COVID-19 infections and almost never die of it (CDC COVID-19 Response Team, 2020; Porcheddu, et al., 2020). Few factors clearly differentiate this age group from others in terms of decreased disease risk except for near universal vaccination, across most of the developed world, for both streptoococcal and Hemophilus influenzae infections, usually by the second year of life (see TABLE 1 for data and references). In addition, children too young to be vaccinated are likely protected by antiviral milk proteins such as casein, lactoferrin and immunoglobulins derived from their mother's or from cow's, goat's or sheep's milk (Sun and Jenssen, 2012). Notably, lactoferrin has been shown to block the SARS coronavirus from infecting cells (Lang, et al., 2011), lactoferrin production is up-regulated during 
coronavirus infection (Reghunathan, et al., 2005), and ingestion of exogenous lactoferrin enhances protection against lung sepsis (Han, et al., 2019).

Second, individuals at high risk for streptococcal and haemophilus infections are exactly the groups of people at high risk of severe COVID-19 infections and complications. The risks for invasive pneumococcal disease (IPD) in adults are, "chronic cardiovascular, pulmonary, liver and kidney diseases, diabetes mellitus, neurological disorders and defects in immune defenses. Compared with healthy adults, individuals with chronic heart and lung diseases and diabetes mellitus have a three-to six-fold increased risk of IPD, and those who are severely immunocompromised have a 23-48-fold increased risk. Adults who have asthma or who smoke tobacco are also at increased risk for IPD” (Fedson, et al., 2011). The same risks attend Hemophilus influenzae type B (Hib) infection (Nix, et al., 2012).

Third, as in the previous SARS-CoV outbreaks, (Zahariadis, et al., 2006), COVID-19 mortality and serious morbidity is highly associated with pneumococcal and haemophilus co-infections, as well as other, secondary infections (Xia, et al., 2020; Wang, et al., 2020). Such patients invariably have severe eosinopenia ( $\mathrm{Li}$, et al., 2020; Zhang, et al., 2020), which is an accurate indicator of systemic bacterial infection (Lavoignet, et al., 2019). Below 15/mm3, eosinopenia can differentiate bacterial from viral infection with reasonable accuracy (Debray, et al., 2019). Unfortunately, despite the well-known fact that viral infections of the lungs predispose to bacterial super-infection (Fainstein, et al., 1980; George, et al., 1983), physicians often fail to test for such co-infections (Ljungström, et al., 2017) or do so using inappropriate tests using sputum or nasal discharge rather than lung aspiration or biopsy.

Fourth, it follows logically from the hypothesis that national rates of vaccination against streptococcal and Hib infections should correlate inversely with risk of severe COVID-19 disease and fatality. It is also possible that exogenous intake of casein and lactoferrin by ingestion of milk products might enhance protection against COVID-19 infection. As TABLES 1 and 2 and FIGURE 1 demonstrate, pneumococcal vaccinations appear to lessen the risk of COVID-19 infection, while other vaccinations do not, nor is there an association between COVID-19 infection and milk intolerance or milk consumption, at least at a national level.

\begin{tabular}{|c|c|c|c|c|c|c|c|c|c|c|c|c|c|}
\hline Country & $\begin{array}{l}\text { Cases } \\
\text { of } \\
\text { COVI } \\
\text { D-19 } \\
\text { per } \\
\text { millio } \\
\mathrm{n}(8 \\
\text { April } \\
2020)\end{array}$ & $\begin{array}{l}\text { Deaths } \\
\text { from } \\
\text { COVID- } \\
19 \text { per } \\
\text { million } \\
\text { people } \\
\text { (as of } 29 \\
\text { March } \\
2020\end{array}$ & $\begin{array}{l}\text { PPV23 or } \\
\text { PCV13 } \\
\text { Strepto- } \\
\text { coccal } \\
\text { vaccine } \\
\text { coverage } \\
\text { rate } \\
\text { among } \\
\text { adults (\%) } \\
\text { over } 65\end{array}$ & $\begin{array}{l}\text { PCV13 } \\
\text { Strepto- } \\
\text { coccal } \\
\text { vaccine } \\
\text { coverage } \\
\text { in infants } \\
<2 \\
\text { (PCV7 } \\
\text { rate)) }\end{array}$ & $\begin{array}{l}\text { Hib } \\
\text { in } \\
\text { infants } \\
+[\mathrm{WHO}]\end{array}$ & $\begin{array}{l}\text { Influenza } \\
\text { vaccine } \\
\text { coverage } \\
\text { rate (\%) } \\
\text { among } \\
\text { adults } \\
\text { over } 60\end{array}$ & $\begin{array}{l}\text { Influenza } \\
\text { vaccine } \\
\text { coverage } \\
\text { rate (\%) } \\
\text { among } \\
\text { adults } \\
18-59\end{array}$ & $\begin{array}{l}\text { BCG } \\
2010- \\
2018 \\
\text { [WHO] }\end{array}$ & $\begin{array}{l}\text { Polio } \\
\text { vacc. } \\
\text { (POL3) } \\
\text { [WHO] }\end{array}$ & $\begin{array}{l}\text { DTP } \\
\text { vacc. } \\
\text { [WHO] }\end{array}$ & $\begin{array}{l}\text { Measles } \\
\text { vacc. } \\
\text { (MCV) } \\
{[\mathrm{WHO}]}\end{array}$ & $\begin{array}{l}\text { \% Adult } \\
\text { Milk } \\
\text { Intol- } \\
\text { erant } \\
\text { @ }\end{array}$ & $\begin{array}{l}\text { Milk } \\
\text { Consum } \\
\text { ption } \\
\text { kg/pers } \\
\text { on/year } \\
\text { (2013) } \\
\text { @@ }\end{array}$ \\
\hline Spain & 5100 & 522 & $25-41$ & $0 \&\left(61^{*}\right)$ & 94 & $60^{\wedge}$ & $27.6^{\wedge}$ & 0 & 97 & 93 & 94 & 29 & 164 \\
\hline Belgium & 4263 & 670 & 29 & $0 \&(96)$ & 97 & $63^{\wedge}$ & $35-44^{\wedge}$ & 0 & 99 & 98 & 85 & 15 & 236 \\
\hline Ireland & 4150 & 246 & 33 & $0 \&(94)$ & 94 & $62^{\wedge}$ & $23^{\wedge}$ & $80-0$ & 94 & 94 & 89 & 4 & 291 \\
\hline $\begin{array}{l}\text { Switzer- } \\
\text { land }\end{array}$ & 3570 & 202 & $2.1 * *$ & $88^{*}$ & 95 & $39>$ & & 0 & 96 & 96 & 89 & 5 & 319 \\
\hline Italy & 3408 & 467 & $20-31$ & $0 \&\left(49^{*}\right)$ & 94 & $60^{\wedge}$ & & 0 & 95 & 95 & 89 & 72 & 247 \\
\hline US & 3350 & 197 & $61.3-70$ & $83-92$ & 92 & $63-68$ & $37-45$ & 0 & 96 & 94 & 97 & 36 & 255 \\
\hline UK & 2556 & 401 & $34-53$ & 92 & 94 & $82-85$ & $63-64^{\wedge}$ & 0 & 94 & 94 & 88 & 12 & 232 \\
\hline Portugal & 2535 & 101 & 10 & 72- 98 & 99 & $68>$ & 30.5 & 21 & 99 & 99 & 96 & 40 & 205 \\
\hline France & 2501 & 363 & 35 & $71 *-92$ & 95 & $63^{\wedge}$ & & $44-0$ & 96 & 96 & 83 & 36 & 241 \\
\hline $\begin{array}{l}\text { Nether- } \\
\text { lands }\end{array}$ & 2340 & 288 & $0.5-3$ & $93-94$ & 93 & $79^{\wedge}$ & & 0 & 93 & 93 & 83 & 12 & 341 \\
\hline
\end{tabular}




\begin{tabular}{|c|c|c|c|c|c|c|c|c|c|c|c|c|c|}
\hline Sweden & 2150 & 265 & 36 & 97 & 97 & $49^{\wedge}$ & & 26 & 97 & 97 & 95 & 7 & 341 \\
\hline Germany & 2002 & 280 & 50.9 & $79 *-85$ & 92 & $41-50^{\wedge}$ & 8.8 & 0 & 98 & 96 & 93 & 16 & 259 \\
\hline Austria & 1726 & 65 & $50 \#$ & 85 & 85 & & & 0 & 92 & 85 & 84 & 22 & 258 \\
\hline Israel & 1661 & 25 & 72 & 95 & 98 & 59 & & 0 & 98 & 98 & 96 & 89 & 193 \\
\hline Canada & 1582 & 10 & 37 & 81 & 91 & 64 & 32 & 0 & 91 & 91 & 87 & 59 & 188 \\
\hline Iran & 1160 & 74 & 1.2 & $0-1$ & 99 & 12 & 6 & 99 & 99 & 99 & 98 & 88 & 47 \\
\hline $\begin{array}{l}\text { New } \\
\text { Zealand }\end{array}$ & 320 & 4 & 60 & 96 & 92 & & 73 & 2 & 95 & 93 & 90 & 10 & 137 \\
\hline Australia & 271 & 4 & $70-80$ & $91-95$ & 94 & $79-82$ & $40-49$ & 0 & 95 & 95 & 93 & 44 & 234 \\
\hline Greece & 242 & 13 & 34 & 99 & 99 & 70 & $19^{\wedge}$ & $91-0$ & 99 & 99 & 83 & 55 & 255 \\
\hline S. Korea & 207 & 5 & $57.3-62.4$ & 97 & 98 & 74 & 57 & 98 & 98 & 98 & 97 & 100 & 29 \\
\hline Mexico & 141 & 14 & 62 & $88-92$ & 88 & 63 & & 96 & 88 & 88 & 99 & 48 & 112 \\
\hline Japan & 34 & 1 & 74 & 99 & 99 & 27 & $19-39.5$ & 99 & 99 & 99 & 93 & 73 & 72 \\
\hline
\end{tabular}

TABLE 1: Cases and deaths from COVID-19 per million population for countries (as of 1 May 2020), selected for availability of the range of required data, compared with vaccination rates with pneumococcal vaccines within various age groups (see text for vaccine descriptions); vaccination with Hemophilus influenzae type B vaccine (Hib); and influenza vaccine. Data are arranged by COVID-19 death rate. Some data were not available from sufficient countries to permit useful comparisons, including infant influenza vaccination rates and Hib vaccination rates in groups other than infants and so these data are not included. Note that data from China have been excluded because serious concerns have been reported about the data available at this time; vaccination rate data were often lacking as well. DTP is diphtheria-tetanus-pertussis vaccine; BCG is Bacillus Calmette-Guerin (tuberculosis) vaccine; vacc. Is short for vaccine. SOURCES: @ (Storhaug, et al., 2017); @@ (Milk Consumption, 2020); \& Spain and Belgium use PCV7 resulting in reemergence of pneumococcal pneumonias (Arencibia Jiménez, et al., 2014; Ciruela, 2018; Desmet, et al., 2018); * Gervaix, et al., 2014; ^ Mereckiene, 2017; + WHO, 2020; > Blank, et al., 2018; \# estimated from accumulated yearly vaccinations. Austria (Richter, et al., 2019); France (Contou, et al., 2020); Germany (Theidel, et al., 2013; Pletz, et al., 2016); Greece (Maraki, et al., 2018); US (FluVaxView; Wateska, et al., 2020; Zhang, et al., 2018; Sings, 2017; Williams, et al., 2016); UK (Tolman, et al., 2016); Australia (Hull, et al., 2019; Yang, et al., 2019; Dyda, et al., 2016); Japan (Naito, et al., 2020; Takeda, et al., 2019; Shibata, et al., 2019; Kajikawa, et al., 2019; Kumar, et al., 2014); S. Korea (Song, et al., 2013; Yang, et al., 2015; Kim, et al., 2016; Park, et al., 2019; Yang, et al., 2020); IRELAND (Corcoran, et al., 2018); Italy (Giammanco, et al., 2018; Baldo, et al., 2016; Tozzi, et al., 2014; Fedson, 2011); Spain (Ciruela, et al., 2018; Arencibia Jiménez, et al., 2014; Fedson, 2011); Canada (Kaplan, et al., 2019; Farmanara, et al., 2018); Portugal (Kislaya, et al., 2019); Netherlands (Vestjens, et al., 2019); Switzerland ** NB no current data available (Büla, et al., 1996). SLOVAKIA (Lahocka, et al., 2016; ** NB no current data available: Madar, et al., 2005). Mexico (Cruz-Hervert, et al., 2013). ISRAEL (Schwarz, et al., 2013). TURKEY (Demirdogen, et al., 2017; Satman, e tla., 2013; Özsu, et al., 2011); IRAN (Shokouhi, et al., 2015; Ezoji, et al., 2019).

TABLE 1 supports the idea that Hib vaccination may have a protective effect particularly among children to whom it is almost universally administered [WHO] (TABLE 1). Vaccination with Hib is, conversely, almost completely absent in adults of any age in any country, potentially leaving adults, especially the elderly in whom immunity is fading, at risk. Notably, while most adults between 18 and 65 carry limited natural immunity to $\mathrm{Hib}, 90 \%$ are carriers of the bacteria and thus a risk to the elderly and immune-compromised ( $\mathrm{Nix}, 2012)$. Fortunately, adults in regions with high rates of Hib vaccination are 
indirectly protected by significant levels of herd immunity (Cohen, et al., 2010). However, it must be noted that Hib vaccine inoculation rates are five to twelve percent lower in some immigrant populations in London than the average (Tiley, et al., 2018) and even lower among African Americans in many cities particularly hard-hit by COVID-19 such as Detroit, Michigan, (MDHHS, 2020) and New Orleans, Louisiana (Louisiana, 2020) as compared with state and national averages. One can assume that similar disparities related to socio-economic, ethnic and racial factors exist in other populations as well, putting some groups at higher risk of $H$. influenzae complications. Anti-vaccination groups will also be at unusual risk.

While it is well-established that infants gain significant protection against disease from their mother's milk, there is no evidence from this study that milk intolerance, on the one hand, or milk ingestion on the other, are correlated either with enhanced or decreased risk of COVID-19 (TABLE 1; FIGURE 1). These data may argue against the efficacy of milk antiviral proteins against COVID-19 or, equally likely, that the amount of active proteins normally consumed through milk products is too small to affect normal immune function. Given the proven effectiveness of ingesting large quantities of lactoferrin as a protection against viruses (Sun \& Jenssen, 2012; Lang, et al., 2011; Han, et al., 2019), clinical trials might still be warranted.

The story for pneumococcal vaccines is more complicated since several types have been used over the past two decades and older versions with incomplete serotype coverage are still used in some populations. The 23-valent polysaccharide pneumococcal vaccine (PPV23) protects against the 23 most common serotypes of pneumococci, as compared with the 13-valent pneumococcal conjugate vaccine (PCV13) or earlier versions that protected against either 7 or 10 serotypes (PCV7 and PCV10). TABLE 1 demonstrates that pneumococcal vaccination rates are significantly lower than Hib vaccination rates among children and that they vary widely by nationality among adults. Thus, according to the hypothesis, pneumococcal vaccination rates should be a better measure of COVID-19 risk of infection and rate of death.

Indeed, a significant inverse correlation exists between combined rates of childhood-plus-adult pneumococcal vaccination with PPV23 or PCV13 and lower rates of COVID-19-associated cases (TABLE 1, TABLE 2, FIGURE 1). In other words, pneumococcal vaccination lowers the risk of COVID-19 infection. Thus, those nations with the lowest per capita cases (and often deaths as well) from COVID-19, such as Australia, Canada, Korea and Japan, are those that have the highest combined rates of pneumococcal vaccination in both infants (using PCV13) and over-64 adult coverage (60-70\%). Conversely, the coverage rate for adults 65 and over in most European countries ranged between 20\% and $30 \%$ and is associated with much higher rates of infection and death from COVID-19. More specifically in Italy, the cumulative coverage rates ranged from $26.3 \%$ to $31 \%$ and was about $23 \%$ in adults 18 to 64 with underlying risk conditions (Alicino, et al., 2014). More generally, nations such as Spain, Italy and Belgium that have utilized PCV7 in children rather than PCV13 (and thus protect against only half the common strains) have very high rates of COVID-19, presumably because they leave the population unprotected against half of the most common strains of pneumococci.

A weaker inverse correlation exists between combined childhood-plus-adult pneumococcal vaccination and COVID-19 rates of death suggesting that individuals not protected against pneumococci are at higher risk death. Combined rates of childhood-plus-adult pneumococcal vaccination is a much better predictor of protection against COVID-19-associated morbidity and mortality than either childhood or adult vaccination alone (FIGURE 1; TABLE 2). Unfortunately, data on pneumooccocal 
vaccination rates among at-risk adults $18-64$ was too spotty to be included here in the statistical analyses but one would expect that higher rates of such vaccination among this age group would add an even greater predictive quality to the analysis.

COVID-19 CASE RATE VS. SUM PNEUMOCOCCAL VACCINATION RATES

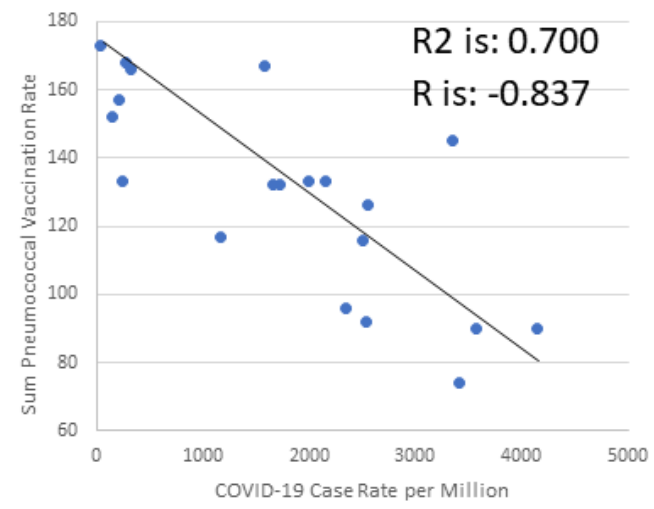

COVID-19 CASE RATE VS. INFANT PNEUMOCOCCAL VACCINATION RATE

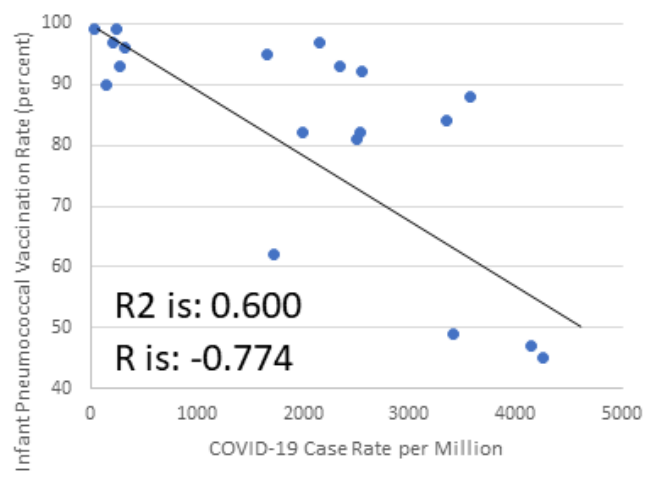

COVID-19 DEATH RATE VS. SUM PNEUMOCOCCAL VACCINATION RATES

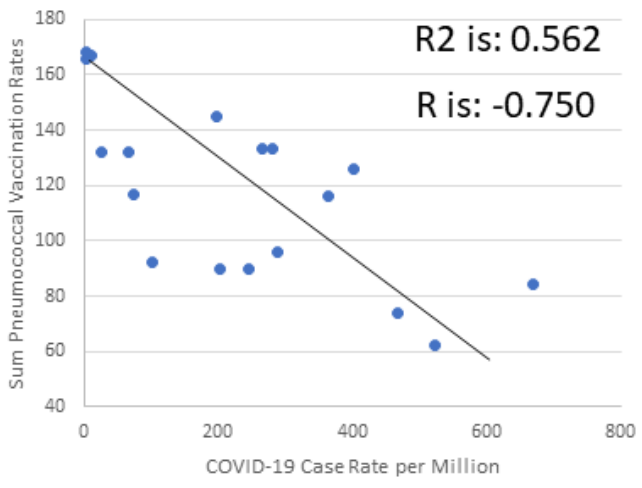

COVID-19 CASE RATE VS. ADULT PNEUMOCOCCAL VACCINATION RATE

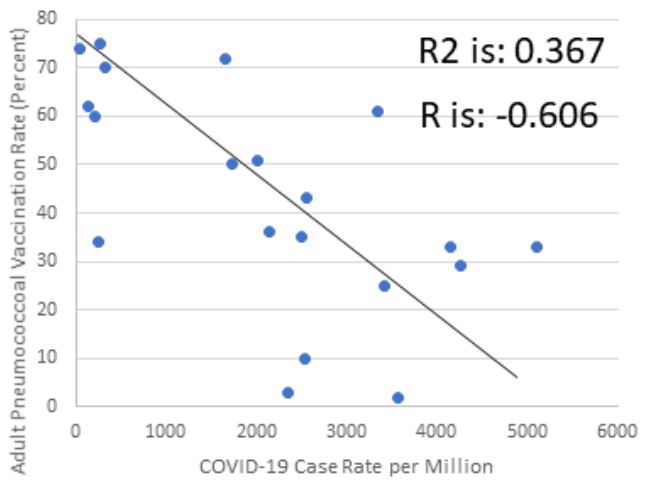

FIGURE 1: Scatter plots for the pneumococcal vaccination data from TABLE 1 compared with COVID-19 rates of cases and deaths. There is a significant inverse correlation between the sum of childhood and adults-65-and-over pneumococcal vaccination rates and case rates of COVID-19 infection. This sum correlates more poorly with COVID-19 death rates. Childhood pneumococcal vaccination rates alone and adult vaccination rates alone have even poorer correlations with case rates. The correlations are even worse between COVID-19 death rates and the separate vaccination rates (TABLE 2) suggesting that the main effect that pneumococcal vaccination has is in prevention of COVID-19 infection. The lower correlations with death rates may be a consequence of people who die of COVID-19 being more likely to have been unvaccinated. Correlation coefficients were calculated using (Agrimetsoft, 2019).

\begin{tabular}{|l|l|l|}
\hline & $\begin{array}{l}\text { COVID-19 } \\
\text { CASE Rate }\end{array}$ & $\begin{array}{l}\text { COVID-19 } \\
\text { CASE Rate }\end{array}$ \\
\hline
\end{tabular}

\begin{tabular}{|l|l|l|}
\hline & $\begin{array}{l}\text { COVID-19 } \\
\text { DEATH Rate }\end{array}$ & $\begin{array}{l}\text { COVID-19 } \\
\text { DEATH Rate }\end{array}$ \\
\hline
\end{tabular}




\begin{tabular}{|c|c|c|}
\hline Vaccination & $\begin{array}{l}\text { Correlation } \\
\text { Coefficient } \mathrm{R}^{2}\end{array}$ & $\begin{array}{l}\text { Pearson's } \\
\text { Correlation } \\
\text { Coefficient, R }\end{array}$ \\
\hline $\begin{array}{l}\text { Sum Adult + } \\
\text { Infant } \\
\text { Pneumococcal }\end{array}$ & 0.700 & -0.837 \\
\hline $\begin{array}{l}\text { Pneumococcal } \\
\text { Infants }\end{array}$ & 0.600 & -0.774 \\
\hline $\begin{array}{l}\text { Pneumococcal } \\
\text { Adults }>64\end{array}$ & 0.358 & -0.598 \\
\hline Hib Infants & 0.000 & -0.022 \\
\hline BCG & 0.178 & -0.422 \\
\hline $\begin{array}{l}\text { Influenza } \\
\text { Adults 18-59 }\end{array}$ & 0.064 & -0.253 \\
\hline $\begin{array}{l}\text { Influenza } \\
\text { Adults >59 }\end{array}$ & 0.002 & -0.048 \\
\hline Polio (OPV2) & 0.015 & 0.122 \\
\hline DTP & 0.000 & -0.017 \\
\hline $\begin{array}{l}\text { Measles } \\
(\mathrm{MCV})\end{array}$ & 0.033 & -0.182 \\
\hline $\begin{array}{l}\text { Lactose } \\
\text { Intolerance }\end{array}$ & 0.211 & -0.459 \\
\hline $\begin{array}{l}\text { Milk } \\
\text { Consumption }\end{array}$ & 0.244 & 0.494 \\
\hline
\end{tabular}

\begin{tabular}{|c|c|c|}
\hline Vaccination & $\begin{array}{l}\text { Correlation } \\
\text { Coefficient } \\
\mathrm{R}^{2}\end{array}$ & $\begin{array}{l}\text { Pearson's } \\
\text { Correlation } \\
\text { Coefficient, R }\end{array}$ \\
\hline $\begin{array}{l}\text { Sum Adult + } \\
\text { Infant } \\
\text { Pneumococcal }\end{array}$ & 0.562 & -0.750 \\
\hline $\begin{array}{l}\text { Pneumococcal } \\
\text { Infants }\end{array}$ & 0.488 & -0.699 \\
\hline $\begin{array}{l}\text { Pneumococcal } \\
\text { Adults }>64\end{array}$ & 0.273 & -0.522 \\
\hline Hib Infants & 0.000 & 0.007 \\
\hline BCG & 0.197 & -0.443 \\
\hline $\begin{array}{l}\text { Influenza } \\
\text { Adults 18-59 }\end{array}$ & 0.016 & -0.127 \\
\hline $\begin{array}{l}\text { Influenza } \\
\text { Adults }>59\end{array}$ & 0.002 & -0.049 \\
\hline Polio IPV & 0.013 & 0.114 \\
\hline DTP & 0.003 & 0.052 \\
\hline Measles MCV & 0.118 & -0.343 \\
\hline $\begin{array}{l}\text { Lactose } \\
\text { Intolerance }\end{array}$ & 0.180 & -0.424 \\
\hline $\begin{array}{l}\text { Milk } \\
\text { Consumption }\end{array}$ & 0.154 & 0.393 \\
\hline
\end{tabular}

TABLE 2: Correlation coefficients (R2) and Pearson's correlation coefficient (R) for vaccination rates for the nations in TABLE 1 as a function of COVID-19 rates of death per million or rates of diagnosed cases per million. R2 and R calculated using Agrimetsoft (2019). In order to account for the use of PCV7 rather than PCV13 in some countries, the adult pneumococcal vaccination rates for the PCV7 countries were halved to reflect the fact that they protect against half of the serotypes of the PCV13 vaccine. Hib is Haemophilus influenzae type B vaccine; BCG is Bacillus Calmette-Guerin (tuberculosis) vaccine; OPV is oral polio virus vaccine; DTP is diphtheria-tetanus-pertussis vaccine; MCV is measle-containing vaccines.

TABLE 2 demonstrates the lack of correlation between COVID-19 rates of death and rates of cases as a function of Influenza, Hib, Bacillus-Calmette-Guerin (BCG) tuberculosis vaccination, oral polio vaccination, measles containing vaccines and diphtheria-pertussis-tetanus vaccination rates. A recent 
manuscript claims that a very significant inverse correlation exists between a nation having a BCG vaccination policy and risk of COVID-19 morbidity or mortality (Miller, et al., 2020) and that study has already led to several nations beginning clinical trials to test the efficacy of BCG vaccine to prevent COVID-19 infection. This study contradicts that finding. Ten of the nations for whom data is presented in TABLE 1 have had BCG vaccination during the period 2010 to the present but these nations are relatively randomly distributed among the COVID-19 morbidity and mortality data. More importantly, most of the nations in TABLE 1 have never had BCG vaccination, yet their COVID-19 morbidity and mortality risks range from the highest in the world (e.g., Spain and Italy) to the lowest (e.g., New Zealand and Australia). Thus, something other than BCG vaccination must mediate this two-orders-of-magnitude difference in risks. Equally importantly, China has had mandatory BCG vaccination for children for decades with rates of compliance over 99\% (WHO), yet China was not protected against the emergence of COVID-19. Moreover, the hypothesis that BCG can protect against COVID-19 is completely incompatible with the fact that morbidity among children is very low and mortality almost non-existent across all nations, including all of those used in this study, regardless of BCG vaccination policy. Whatever the factor is that mediates COVID-19 risk of infection and death, it is not BCG. Similarly, it has been reported that clinical trials have begun utilizing inactivated polio vaccine to prevent or treat COVID-19 infection (Samaranayaki, 2020). The data in TABLE 2 once again argues against it having any effect.

Another factor that needs to taken into account but which is not included in the analyses presented here is herd immunity. The data presented in TABLE 1 suggest that countries with high COVID-19 death rates tend to have low childhood vaccination rates for pneumococci. Hib and pneumococcal vaccines are strong determinants of herd immunity protecting at-risk adults and the elderly from pneumonia risk (Lexau, et al., 2005; Isaacman, et al., 2008; Pletz, et al., 2016; Richter, et al., 2019; Wiese, et al., 2019). In a few countries, high levels of infant vaccination with PCV-13 seem to balance out low levels of adult vaccination, as exemplified by the case of the Netherlands and Switzerland (TABLE 1). However, not all nations have adopted PCV-13 or have only done so recently and incompletely. Thus, childhood vaccination rates against pneumococcal infections correlate poorly with COVID-19 deaths per capita in individual regions of Italy. Baldo, et al. (2016) documented the probable reason for this lack of correlation: Italy has, until very recently, relied on the PCV-7 pneumococcal vaccine, which protects against only seven pneumococcal serotypes, rather than PCV-13, resulting in selection for pneumococcal serotypes in Italy to non-vaccinated types and a documented loss of herd immunity for the elderly. Similarly, many regions in Spain not only have very low rates of adult and childhood vaccination but have relied on PCV7 or PCV10 for both groups, again limiting herd immunity against many serotypes (Arencibia Jiménez, et al., 2014; Ciruela, 2018). Belgium also saw a reemergence of pneumonia deaths involving previously herd-immunized strains of $S$. pneumonia after recently switching from PCV13 to PCV7 (Desmet, et al., 2018). Thus, Italy, Spain and Belgium lacked the protection against COVID-19 infection hypothesized here.

To reiterate, the best predictor of protection afforded by pneumococcal vaccination, or lack thereof, documented in TABLES 1 and 2 and FIGURE 1 is a combination of infant, at-risk-adults 18-64, and 65 -and-over adult vaccination rates. This tri-partite coverage effect is more clearly illustrated in TABLE 3, which compares rates of COVID-19 cases and deaths per million population in states of the United States with rates of pneumococcal vaccination across all three age groups. States with high rates of COVID-19 infections and deaths average 5\% fewer vaccinations in each age group compared with 
states with the lowest rates of COVID-19 infections and deaths. Assuming that the lower vaccination rate in each age group increases the risk for the next older age group because of lowered herd immunity, it follows that high-infection-rate states have a cumulative dearth of vaccinations of three times that $5 \%$ average, or $15 \%$ percent overall as compared with low-infection states. The impact on decreased herd immunity might be even greater than that. In extreme cases, such as New York City the epicenter of infections and deaths in the United States - and Washington, D. C. (the District of Columbia), which has a very large minority population, the cumulative deficit in vaccinations is in the range of $25 \%$, or an average deficit of about $8 \%$ in each age group (TABLE 3 ). Similar deficits can be found in other cities where COVID-19 infections and deaths are unusually high, such as Detroit, Michigan (20 deaths $/ 100,000$ people as of 4 April 2020). There, the coverage rates in infants are $57.2 \%$ for Hib and $72.4 \%$ for PCV13 as compared with the statewide rates of $74 \%$ and $82.6 \%$ (the latter similar to U. S. national averages). Only 31.8\% of adults in Detroit 65 and over received PPV23 as compared with a statewide average of $51.6 \%$ and a national average of over $60 \%$ (MDHHS, 2020). New Orleans, Louisiana has the highest per capita rate of COVID-19 deaths in the United States (36/100,000 as of 4 April 2020) and low rates of infant vaccination (60-68\% coverage of both Hib and PVC-13 in infants) (Louisiana, 2020) similar to those of Italy and Spain. New York City, the next most COVID-19-affected city, also has unusually low infant and adult vaccination rates (see TABLE 3 ). Thus, there is once again a good inverse correlation between combined rates of pneumococcal and Hib vaccination and risk of COVID-19 infection and death at the level of individual states and cities.

\begin{tabular}{|c|c|c|c|c|c|c|c|}
\hline STATE & $\begin{array}{l}\text { COVID- } \\
19 \\
\text { CASES } \\
\text { (PER } \\
\text { MILLION) }\end{array}$ & $\begin{array}{l}\text { COVID- } \\
19 \\
\text { DEATHS } \\
\text { (PER } \\
\text { MILLION) }\end{array}$ & $\begin{array}{l}\text { PCV-13 } \\
\text { VACCINE } \\
\text { COVERAGE } \\
\text { CHILDHOOD } \\
\text { (\%) } 2017\end{array}$ & $\begin{array}{l}\text { PNEUMO- } \\
\text { COCCAL } \\
\text { VACCINE } \\
\text { COVERAGE } \\
18-64 \text { AT } \\
\text { RISK (\%) } \\
2017\end{array}$ & $\begin{array}{l}\text { PNEUMO- } \\
\text { COCCAL } \\
\text { VACCINE } \\
\text { COVERAGE } \\
>65(\%) \\
2006\end{array}$ & $\begin{array}{l}\text { SUM } \\
\text { OF } \\
\text { VACC } \\
\%\end{array}$ & $\begin{array}{l}\text { DIFF. } \\
\text { FROM } \\
\text { LOW } \\
\text { IMPACT } \\
\text { STATES }\end{array}$ \\
\hline NEW YORK & $\begin{array}{l}75,983 \\
(3799) \\
\end{array}$ & $\begin{array}{l}1714 \\
(86)\end{array}$ & 74.2 (NYC) & 34.0 (NYC) & 65.9 & 174.1 & -24.0 \\
\hline LOUISIANA & $\begin{array}{l}5237 \\
(1140) \\
\end{array}$ & $\begin{array}{l}239 \\
(50) \\
\end{array}$ & 79.1 & 36.2 & 68.6 & 183.9 & -14.2 \\
\hline NEW JERSEY & $\begin{array}{l}18,696 \\
(2100)\end{array}$ & $\begin{array}{l}267 \\
(30) \\
\end{array}$ & 80.1 & 32.0 & 67.6 & 179.7 & -18.4 \\
\hline WASHINGTON & $\begin{array}{l}5482 \\
(730)\end{array}$ & $\begin{array}{l}225 \\
(30)\end{array}$ & 84.7 & 41.6 & 67.9 & 194.2 & -3.9 \\
\hline MICHIGAN & $\begin{array}{l}7615 \\
(762)\end{array}$ & $\begin{array}{l}259 \\
(26)\end{array}$ & 82.9 & 36.8 & 66.9 & 186.6 & -11.5 \\
\hline CONNECTICUT & $\begin{array}{l}3128 \\
(869) \\
\end{array}$ & $\begin{array}{l}69 \\
(19) \\
\end{array}$ & 89 & 32.3 & 73.1 & 194.4 & -3.7 \\
\hline $\begin{array}{l}\text { DISTRICT OF } \\
\text { COLUMBIA }\end{array}$ & $\begin{array}{l}495 \\
(825)\end{array}$ & $\begin{array}{l}9 \\
(15)\end{array}$ & 88.5 & 30.2 & 54.9 & 173.6 & -24.5 \\
\hline NEVADA & $\begin{array}{l}1278 \\
(430)\end{array}$ & $\begin{array}{l}26 \\
(9)\end{array}$ & 83.9 & 31.2 & 59.0 & 174.1 & -24.0 \\
\hline \multicolumn{3}{|l|}{ AVERAGES } & 82.8 & 34.3 & 65.5 & 182.6 & -15.5 \\
\hline
\end{tabular}




\begin{tabular}{|l|l|l|l|l|l|l|}
\hline MAINE & $\begin{array}{l}344 \\
(264)\end{array}$ & $\begin{array}{l}7 \\
(5)\end{array}$ & 82.2 & 43.1 & 72.2 & 197.5 \\
\hline OREGON & $\begin{array}{l}690 \\
(164)\end{array}$ & $\begin{array}{l}18 \\
(4.3)\end{array}$ & 83.3 & 42.5 & 71.1 & 196.8 \\
\hline WISCONSIN & $\begin{array}{l}1351 \\
(233)\end{array}$ & $\begin{array}{l}25 \\
(4)\end{array}$ & 87.9 & 40.5 & 74.3 & 202.7 \\
\hline KENTUCKY & $\begin{array}{l}59 \\
(131)\end{array}$ & $\begin{array}{l}17 \\
(4)\end{array}$ & 92.4 & 38.0 & 64.3 & 194.7 \\
\hline MINNESOTA & $\begin{array}{l}629 \\
(112)\end{array}$ & $\begin{array}{l}12 \\
(2)\end{array}$ & 79.6 & 33.8 & 78.3 & 191.7 \\
\hline IOWA & $\begin{array}{l}497 \\
(166)\end{array}$ & $\begin{array}{l}7 \\
(2)\end{array}$ & 88.8 & 38.1 & 74.1 & 206.0 \\
\hline NEBRASKA & $\begin{array}{l}177 \\
(90)\end{array}$ & $\begin{array}{l}3 \\
(1.5)\end{array}$ & 89.5 & 38.3 & 75.8 & 203.6 \\
\hline $\begin{array}{l}108 \\
\text { SOUTH } \\
\text { DAKOTA }\end{array}$ & $\begin{array}{l}1 \\
(120)\end{array}$ & 82.5 & 37.2 & 76.9 & 196.6 \\
\hline AVERAGES & & & 86.3 & 39.0 & 72.8 & 198.1 \\
\hline
\end{tabular}

TABLE 3: COVID-19 infections and deaths per million people in selected states and the District of Columbia (Washington, D. C.) in the United States as of 6 April 2020 compared with rates of pneumococcal vaccination among infants, at-risk individuals 18-64, and adults 65 years of age or older. The top group are states with the highest rates of COVID-19 infection and death; the lower group are those with the lowest rates of COVID-19 infection and death. The right-hand columns sum the rates of vaccination across all age groups in order to give a rough numerical summary of that state's overall vaccination rate across all three age groups, assuming that the overall herd immunity protection afforded by vaccination is a function of vaccination in all three groups. The differences between the highdeath-rate states and the low-death-rate groups are provided. Sources: Worldometer, 31 March 2020; Centers for Disease Control, 2006; 2017a; 2017b.

Such local variations appear to mediate COVID-19 risks at local levels worldwide. As noted above for Hib vaccination and inherent in the data in TABLE 3, the international data provided in the TABLE 1 mask significant variations in vaccination rates for pneumococci by socio-economic background, ethnicity, religion (Fry, et al., 2001), and mask local or regional variations (TABLE 2). For example, infant vaccination rates for Hib and pneumococci are significantly lower among African Americans (Jones, et al., 2010) and impoverished inner-city families than among Caucasian Americans with median or higher incomes in the United States (Hill, et al., 2017; Lu, et al., 2015). Pneumococcal vaccination rates among adults over 65 varied from 18\% to 91\%. with the same factors nationally (McLaughlin, et al., 2019) and within neighborhoods in individual cities such as Chicago (Hughes, et al., 2018), Logically, the hypothesis proposed here predicts that medically marginalized communities should have greater susceptibility to coronavirus deaths due to lower rates of pneumococcal and Hib vaccination in both infants and adults so that those with the least ability to afford such devastating disease will be most impacted putting not only them, but everyone, at additional risk of severe infection during influenza and coronavirus pandemics. 
One further twist on the hypothesis is presented by the case of Iran (TABLE 1), where Hib and pneumococcal vaccination rates are so low as to be inconsequential. Iran has, nonetheless, had relatively few COVID-19 cases and deaths (assuming that these figures are not an artifact due to lack of proper testing). One possible interpretation of the Iranian figures is that they disprove the hypothesis being proposed here. Another, however, is that they support it in a way that augers well for many under-developed nations during the continuing COVID-19 pandemic, for Iran's endemic burden of Hib and pneumococcal infections is extremely high, resulting in many deaths but also conferring widespread natural immunity by means of active infection. Because of such natural immunity, nations that have the lowest rates of Hib and pneumococcal vaccination may be as protected against COVID-19 as those with the highest rates of vaccination, while those with inadequate vaccination programs (sufficient to significantly lower natural infections but not sufficient to replace them with widespread artificial immunization) will be at the greatest risk. Thus, nations such as India, Bangledesh, and many African nations may not experience the devastation from COVID-19 that most experts are predicting.

\section{LIMITATIONS OF THE HYPOTHESIS}

The hypothesis that Hib and pneumococcal vaccination rates mediate COVID-19 severity and mortality is based on correlation and should not be taken as proof of causation. The correlation may be due to other factors that these vaccinations are themselves correlated with such as better access to healthcare in general, better nutrition, and so forth. The hypothesis also leaves out many obvious factors that would have to be taken into account in any complete understanding of the pandemic. One is that the figures presented in TABLE 1 (and inherent in the statistical analysis in TABLE 2) represent not only the rate, but also the effectiveness, of vaccination. For high risk groups, this assumption is certainly wrong. It is well-established that elderly patients are less likely to develop protective immunity after vaccination than are young, healthy adults. People with diabetes, alcoholism or other drug addictions, malnutrition, and/or living in poverty may experience the same inefficacy. For example, one of the populations hardest hit by COVID-19 in the U. S. are the Native American people of the Navajo Nation whose case and death rates challenge those of New York City (TABLE 3) and inner-city Detroit. Seventythree percent of adults in the Navajo Nation over 65 have received PPV23 and $54 \%$ of high-risk adults 18-64. However, the effectiveness of the PPV23 vaccine among adults was found to be only $20 \%$ among healthy recipients and between 0 and $5 \%$ among those with diabetes and alcoholism (Bennin, et al., 2003). Ninety-four percent of infants received PCV13 by 2016 (Charley \& Reid, 2017) but 47\% still tested positive for nasal carriage of pneumococci (Charley \& Reid, 2017). Thus, while high vaccination rates may confer significant herd immunity among healthy populations, this assumption may not hold for those groups at highest risk for COVID-19, thereby strengthening the case for improving effective pneumococcal and Hib vaccination.

A second missing factor is other super-infections that have been associated with COVID-19 such as Mycoplasma pneumoniae (Fan, et al., 2020) and various viral, fungal and yeast infections (Wang, et al., 2020). Vaccination against pneumococci and haemophilus should not be considered a complete prophylactic against severe disease or death and it may be necessary to revive development of vaccines against M. pneumoniae (Linchevski, et al., 2009), which would protect against one of the most common coinfection of influenza and coronaviruses (Zahariadis, et al., 2006; Liu, et al., 2019). 
Other factors missing from this account include those defining rates and modes of disease transmission such as population density, frequency and number of interpersonal contacts, the proportion of elderly individuals in a population, availability of testing and timely medical treatment, etc. Thus, the hypothesis should not be over-interpreted as being meant to explain all aspects of COVID19 risk but in the more limited context of why such large disparities exist in these risks among certain populations by age or geographical location. The fact that significant correlations exist between COVID19 case and death rates and pneumococcal vaccination rates is, in light of all these other mediating factors, all the more significant.

\section{TESTS OF THE HYPOTHESIS}

This hypothesis is testable in multiple ways.

First, it should be possible to determine from patient records whether those with serious or fatal cases of COVID-19 are unusually unlikely to have had Strep or Hib vaccinations compared with agematched controls who either had mild cases or did not become infected. The correlation between lack of vaccination and severity of COVID-19 disease is unlikely to be perfect, however, since vaccinations become increasingly ineffective with age and often do not protect the elderly as well as younger people (Westerink, et al., 2012; Papadatou and Spoulou, 2016).

Second, vaccination of high-risk populations such as nursing home and retirement community residents, everyone over the age of 50, and all health-care workers, with Strep and Hib vaccines should significantly lower their risk of serious or fatal COVID-19 infections as it did previously did for influenzarelated deaths (Mahamat, et al., 2013; Yang, et al., 2019). Younger individuals may also benefit from these vaccinations in a time of constant threat of influenza and coronavirus pandemics although this recommendation currently runs counter to the guidelines in the US and most European nations (reviewed in Sing, 2017). However, because current vaccination procedures for el derly adults are only partially effective and antibiotics often fail to cure pre-existing pneumococcal (Fedson, et al., 2011) and Hib (Nix, et al., 2012) infections at time of hospitalization, precautionary vaccination should be taken seriously for everyone. Moreover, vaccination strategies for the elderly should be modified to include a combination of PCV13 and PPV23 in properly timed doses to improve immunity (Westerink, et al., 2012; Papadatou and Spoulou, 2016).

Third, epidemiological studies should demonstrate that COVID-19 has preferentially affected national regions, neighborhoods and groups of people such as anti-vaccine advocates with the lowest rates of pneumococcal and Hib vaccination.

Fourth, several possible mechanisms should be explored as explanations for the correlation between higher Hib and pneumococcal vaccination rates and lower COVID-19 morbidity and mortality: A) Hib and/or pneumococcal vaccines directly protect against COVID-19 infection by means of inducing cross-reactive antibodies (for example, Hib and pneumococcal vaccines are both composed of polysaccharides and COVID-19 is heavily glycosylated, possibly sharing mucoprotein antigens); B) Hib and/or pneumococcal vaccination prevents secondary infection following COVID-19 exposure thereby lowering the risk of severe or fatal complications and keeping COVID-19 symptoms minimal; C) vaccination rates are a stand-in for other factors that more directly control COVID-19 risks. 
Fifth, test every hospitalized coronavirus patient for eosinopenia and those with severe eosinopenia for the presence of streptococci, haemophilus and M. pneumoniae infections using highsensitivity tests. Combined viral-bacterial infections are particularly difficult to diagnose because of a tendency to test only for the expected pathogen (in this case COVID-19) and also because one infection may mask the other (Kumar, et al., 2018; Zahariadis, et al., 2006). Additionally, viral-bacterial coinfections often synergize so that levels of infection that may seem inconsequential may become deadly. For example, Shope demonstrated with regard to swine flu that a combination of the influenza virus with $\mathrm{H}$. influenzae was $100 \%$ fatal at doses of the individual microbes that caused no mortality and, in most experimental animals, no morbidity either (Shope, 1931). Pathologists, who are unfortunately in short supply in most countries, will be needed to carry out autopsies looking for such combined infections in deceased individuals.

Sixth, set up animal models such as those invented by Shope (1931) to explore the effects of combined COVID-19-pneumococcal or COVID-19-Hib infections and the effectiveness of vaccines against pneumococci and Hib in preventing the transmission of severe COVID-19 infections.. On a positive note, Shope demonstrated that vaccination with either one of the causative agents protected against mortality from their combination (Shope, 1931). Not only do Shope's experiments provide a model for setting up COVID-19 animal models to test this hypothesis, they also suggest that the type of protection hypothesized here has been demonstrated to exist for the combination of Hib with influenza.

Finally, the possibility that anti-viral proteins in milk may help to protect against COVID-19 infection is easily testable in both animals and human beings given the inexpensiveness and wide availability of casein and lactoferrin.

RISKS

A caveat is in order: it is not clear at this time whether healthcare providers and other people at high risk of contracting coronavirus should be vaccinated with strep and/or Hib vaccines while at risk for exposure to the virus. Vaccinating on top of an existing coronavirus infection could lead to complications (Westall and Root-Bernstein, 1986). On the other hand, combining $H$. influenzae antigens with influenza vaccines leads to a heightened vaccine response (e.g., Gönczi, 1987; Root-Bernstein, et al., 2013), a possibly beneficial phenomenon.

And a warning: It follows from the hypothesis that one of the most serious risks presented by the present COVID-19 pandemic is that, in some regions such as Italy and Spain, or in some high-density locations such as New York City, Detroit and New Orleans during Mardi Gras, the virus has become conjoined to a synergistic bacterial pandemic so that seriously ill individuals will transmit both infections concomitantly. As Shope (1931) demonstrated in the case of swine-flu-plus-H.-influenzae, such a combination is likely to be far more infectious and fatal, than the individual infections would be, even among healthy people. This effect may explain the extreme risks associated with healthcare providers tending to COVID-19 infected individuals and why some young people are unexpectedly dying. Indeed, concurrent infections between influenza virus and $H$. influenzae or streptococci characterized the great Flu Pandemic of 1918-19 and several subsequent influenza pandemics (Root-Bernstein, et al., 2013; Morens, et al., 2008; McNamee and Harmsen, 2006; Brundage, 2006). Breaking the chain of concurrent infections by means of vaccination against bacteria (and increased use of antibiotics) may therefore be an essential component of any attempt to control the coronavirus pandemic. 


\section{CONCLUSION}

If Hib and pneumococcal vaccinations either indirectly or directly lower COVID-19 morbidity and mortality, then should be possible to mitigate significantly the impact of any future influenza or coronavirus pandemic by investing as soon as possible in mass pneumococcal and Hib vaccination programs worldwide, especially for populations in which the vaccination rate is currently low (Brundage, 2006; Root-Bernstein, et al., 2013). Notably, this vaccination strategy has already proven to be effective in mitigating influenza-associated complications and deaths (Mahamat, et al., 2013; Yang, et al., 2019) so that it will certainly have benefits in terms of decreasing morbidity and mortality associated with yearly influenza epidemics thereby freeing up resources for fighting COVID-19.

Because the more broadly vaccinations are implemented, the stronger both individual immunity and herd immunity becomes, the greater the benefits for everyone. Indeed, every study that has been done of the economic impact of pneumococcal and Hib vaccination programs has shown that for every billion dollars invested in vaccination, several billions are saved in critical care costs for elderly and atrisk patients (Wateska, et al., 2020; Richter, et al., 2019; Zhang, et al., 2018; Ciruela, et al., 2018; Baldo, et al., 2016; Arencibia Jiménez, et al., 2014; Isaacman, et al., 2008 ). Actual savings may be significantly greater since these economic studies have not included the benefits that may accrue from protection against the global economic devastation that a coronavirus or influenza pandemic can cause by shutting down businesses and harming trade.

\section{ACKNOWLEDGEMENTS}

This research was not funded. I thank Franklin Pratt, M. D., Stephen Holve, M. D., Karla Kerlikowske, M. D., Patrick F. Dillon, Ph. D., Valerie E. Foster, Ph. D., Meredith Root-Bernstein, Ph. D., Michele RootBernstein, Ph. D. and Thomas Turkette for their comments and suggestions.

\section{CONFLICTS OF INTEREST}

The author declares that he has no conflicts of interest.

\section{REFERENCES}

AgriMetSoft (2019). Online Calculators. Available on: https://agrimetsoft.com/calculators/correlation\%20coefficient

Alicino C, Paganino C, Orsi A, Astengo M, Trucchi C, Icardi G, Ansaldi F. The impact of 10-valent and 13valent pneumococcal conjugate vaccines on hospitalization for pneumonia in children: A systematic review and meta-analysis. Vaccine. 2017 Oct 13;35(43):5776-5785. doi: 10.1016/j.vaccine.2017.09.005.

Arencibia Jiménez M, Navarro Gracia JF, Delgado de Los Reyes JA, Pérez Torregrosa G, López Parra D, López García P. Missed opportunities in antipneumococcal vaccination. Can something more be done for prevention? Arch Bronconeumol. 2014 Mar;50(3):93-8. doi: 10.1016/j.arbres.2013.09.016.

Baldo V, Cocchio S, Gallo T, Furlan P, Romor P, Bertoncello C, Buja A, Baldovin T. Pneumococcal Conjugated Vaccine Reduces the High Mortality for Community-Acquired Pneumonia in the Elderly: an Italian Regional Experience. PLoS One. 2016 Nov 15;11(11):e0166637. doi:

10.1371/journal.pone.0166637. 
Benin AL, O'Brien KL, Watt JP, Reid R, Zell ER, Katz S, Donaldson C, Parkinson A, Schuchat A, Santosham $M$, Whitney CG. Effectiveness of the 23-valent polysaccharide vaccine against invasive pneumococcal disease in Navajo adults. J Infect Dis. 2003 Jul 1;188(1):81-9

Blank PR, van Essen GA, Ortiz de Lejarazu R, Kyncl J, Nitsch-Osuch A, Kuchar EP, Falup-Pecurariu O, Maltezou HC, Zavadska D, Kristufkova Z, Kassianos G. Impact of European vaccination policies on seasonal influenza vaccination coverage rates: An update seven years later. Hum Vaccin Immunother. 2018;14(11):2706-2714. doi: 10.1080/21645515.2018.1489948

Brundage JF (2006) Interactions between influenza and bacterial respiratory pathogens: implications for pandemic preparedness. Lancet 6: 303-312.

Büla CJ, Closuit A, Meier-Padel S, Bart PA, Schluter L, Rossier P. [Vaccination in elderly patients in rehabilitation: a missed opportunity?]. Schweiz Med Wochenschr. 1996 Nov 30;126(48):2082-6.

Charley M, Reid R. Impact of PCV13 on Carriage. Johns Hopkins Center for American Indian Health. Unpublished lecture, 18 October 2017: https://www.nnhrrb.navajonsn.gov/pdf/2017/2017conf day1/Impact\%20of\%20Routine\%20PCV13\%20on\%20Carriage.pdf

CDC COVID-19 Response Team. Severe Outcomes Among Patients with Coronavirus Disease 2019 (COVID-19) - United States, February 12-March 16, 2020. MMWR Morb Mortal Wkly Rep. 2020 Mar 27;69(12):343-346. doi: 10.15585/mmwr.mm6912e2.

Centers for Disease Control and Prevention (CDC). Influenza and pneumococcal vaccination coverage among persons aged $>$ or $=65$ years--United States, 2004-2005. MMWR Morb Mortal Wkly Rep. 2006 Oct 6;55(39):1065-8.

Centers for Disease Control. 2017a. Pneumococcal vaccination coverage among adults 18-64 years at increased risk and $\geq 65$ years, 2017. https://www.cdc.gov/vaccines/imzmanagers/coverage/adultvaxview/data-reports/general-population/trend/index.html Accessed 1 April 2020

Centers for Disease Control. 2017b. Childhood Pneumococcal Conjugate Vaccine (PCV) Coverage Report. https://www.cdc.gov/vaccines/imz-managers/coverage/childvaxview/data-

reports/pcv/reports/2017.html Accessed 1 April 2020

Chen $\mathrm{CH}$, Wu MS, Wu IC. Vaccination coverage and associated factors for receipt of the 23-valent pneumococcal polysaccharide vaccine in Taiwan: A nation-wide community-based study. Medicine (Baltimore). 2018;97(5):e9773. doi:10.1097/MD.0000000000009773

Ciruela P, Izquierdo C, Broner S, Muñoz-Almagro C, Hernández S, Ardanuy C, Pallarés R, Domínguez A, Jané $M$; Catalan Working Group on Invasive Pneumococcal Disease. The changing epidemiology of invasive pneumococcal disease after PCV13 vaccination in a country with intermediate vaccination coverage. Vaccine. 2018 Nov 29;36(50):7744-7752. doi: 10.1016/j.vaccine.2018.05.026.

Cohen SA, Ahmed S, Klassen AC, Agree EM, Louis TA, Naumova EN. Childhood Hib vaccination and pneumonia and influenza burden in US seniors. Vaccine. 2010 Jun 17;28(28):4462-9. doi:

10.1016/j.vaccine.2010.04.035. 
Contou D, Coudroy R, Colin G, Tadié JM, Cour M, Sonneville R, Mekontso Dessap A, de Prost N; HOPEFUL Study Group. Pneumococcal purpura fulminans in asplenic or hyposplenic patients: a French multicenter exposed-unexposed retrospective cohort study. Crit Care. 2020 Feb 26;24(1):68. doi: 10.1186/s13054020-2769-y.

Corcoran M., J. Mereckiene2 S. Murchan, M. McElligott, D. O’Flanagan, S. Cotter, R. Cunney, H. Humphreys. Is It Time To Review The Vaccination Strategy To Protect Adults Against Invasive Pneumococcal Disease? Irish Med. J. 2018. http://imj.ie/is-it-time-to-review-the-vaccination-strategy-toprotect-adults-against-invasive-pneumococcal-disease/

Cruz-Hervert LP, Ferreira-Guerrero E, Díaz-Ortega JL, Trejo-Valdivia B, Téllez-Rojo MM, MonguaRodríguez N, Hernández-Serrato MI, Montoya-Rodríguez AA, García-García L. [Vaccination coverage in young, middle age and elderly adults in Mexico]. [Article in Spanish] Salud Publica Mex. 2013;55 Suppl 2:S300-6.

Debray A, Nathanson S, Moulin F, Salomon J, Davido B. Eosinopenia as a marker of diagnosis and prognostic to distinguish bacterial from aseptic meningitis in pediatrics. Eur J Clin Microbiol Infect Dis. 2019 Oct;38(10):1821-1827. doi: 10.1007/s10096-019-03614-y.

Desmet S, Verhaegen J, Van Ranst M, Peetermans W, Lagrou K. Switch in a childhood pneumococcal vaccination programme from PCV13 to PCV10: a defendable approach? Lancet Infect Dis. 2018 Aug;18(8):830-831. doi: 10.1016/S1473-3099(18)30346-3.

Dyda A, Karki S, Hayen A, Maclntyre CR, Menzies R, Banks E, Kaldor JM, Liu B. Influenza and pneumococcal vaccination in Australian adults: a systematic review of coverage and factors associated with uptake. BMC Infect Dis. 2016 Sep 26;16(1):515.

Ezoji, Khadijeh \& Yaghoubi, Mohsen \& Nojomi, Marzieh \& Mahmoody, Sussan \& Zahraie, Seyed \& Moradi-Lakeh, Maziar \& Tabatabaei, Sedigheh \& Karimi, Abdollah. (2019). Cost-effectiveness of introducing the pneumococcal conjugate vaccine for children under 5 years in the Islamic Republic of Iran. Eastern Mediterranean Health Journal. 25. 10.26719/emhj.19.039.

Fainstein V, Musher DM, Cate TR. Bacterial adherence to pharyngeal cells during viral infection. J Infect Dis. 1980 Feb;141(2):172-6.

Fan BE, Lim KGE, Chong VCL, Chan SSW, Ong KH, Kuperan P. COVID-19 and mycoplasma pneumoniae coinfection. Am J Hematol. 2020 Mar 15. doi: 10.1002/ajh.25785.

Farmanara N, Sherrard 3, Dubé È, Gilbert NL. Determinants of non-vaccination against seasonal influenza in Canadian adults: findings from the 2015-2016 Influenza Immunization Coverage Survey. Can J Public Health. 2018 Jun;109(3):369-378. doi: 10.17269/s41997-018-0018-9.

Fedson DS1, Nicolas-Spony L, Klemets P, van der Linden M, Marques A, Salleras L, Samson SI. Pneumococcal polysaccharide vaccination for adults: new perspectives for Europe. Expert Rev Vaccines. 2011 Aug;10(8):1143-67. doi: 10.1586/erv.11.99.

FluVaxView. https://www.cdc.gov/flu/fluvaxview/coverage-1819estimates.htm Accessed 30 March 2020 
Fry AM, Lurie P, Gidley M, Schmink S, Lingappa J, Fischer M, Rosenstein NE. Haemophilus influenzae Type $b$ disease among Amish children in Pennsylvania: reasons for persistent disease. Pediatrics. 2001 Oct;108(4):E60.

George RC, Broadbent DA, Drasar BS. The effect of influenza virus on the adherence of Haemophilus influenzae to human cells in tissue culture. Br J Exp Pathol. 1983 Dec; 64(6): 655-9.

Gervaix A, Ansaldi F, Brito-Avô A, Azzari C, Knuf M, Martinón-Torres F, Tuerlinckx D, Tin Htar MT, Syrogiannopoulos GA. Pneumococcal vaccination in Europe: schedule adherence. Clin Ther. 2014 May;36(5):802-12.e1. doi: 10.1016/j.clinthera.2014.03.001

Giammanco GM,Bechini A, Urone N, Bonura F, Muli SL, De Grazia S, Bellini I,Tiscione E, Boccalini S, Nastasib A. Is Italian population protected from Poliovirus? Results of a seroprevalence survey in Florence, Italy. Italy IPV: Hum Vaccin Immunother. 2018; 14(9): 2248-2253. doi:

10.1080/21645515.2018.1475812

Gönczi S (1987) Sensitization to the influenza virus in a combined experimental infection. Biull Eksp Biol Med 103: 603-606.

Han N, Li H, Li G, Shen Y, Fei M, Nan Y. Effect of bovine lactoferrin as a novel therapeutic agent in a rat model of sepsis-induced acute lung injury. AMB Express. 2019 Oct 31;9(1):177. doi: 10.1186/s13568019-0900-8.

Hill HA, Elam-Evans LD, Yankey D, Singleton JA, Kang Y. Vaccination Coverage Among Children Aged 1935 Months - United States, 2016. MMWR Morb Mortal Wkly Rep. 2017 Nov 3;66(43):1171-1177. doi: 10.15585/mmwr.mm6643a3.

Hughes MM, Saiyed NS, Chen TS. Local-Level Adult Influenza and Pneumococcal Vaccination Disparities: Chicago, Illinois, 2015-2016. Am J Public Health. 2018 Apr;108(4):517-523. doi: 10.2105/AJPH.2017.304257.

Hull B, Hendry A, Dey A, Brotherton J, Macartney K, Beard F. Annual Immunisation Coverage Report 2017. Commun Dis Intell (2018). 2019 Nov 18;43. doi: 10.33321/cdi.2019.43.47.

leven M, Coenen S, Loens K, Lammens C, Coenjaerts F, Vanderstraeten A, Henriques-Normark B, Crook D6, Huygen K, Butler CC, Verheij TJM, Little P, Zlateva K, van Loon A, Claas ECJ, Goossens H; GRACE consortium. Aetiology of lower respiratory tract infection in adults in primary care: a prospective study in 11 European countries. Clin Microbiol Infect. 2018 Nov;24(11):1158-1163. doi:

10.1016/j.cmi.2018.02.004.

Isaacman DJ, Strutton DR, Kalpas EA, Horowicz-Mehler N, Stern LS, Casciano R, Ciuryla V. The impact of indirect (herd) protection on the cost-effectiveness of pneumococcal conjugate vaccine. Clin Ther. 2008 Feb;30(2):341-57. doi: 10.1016/j.clinthera.2008.02.003.

Jones LG, Zhang Y, Ahmed MI, Ekundayo OJ, Akhter S, Sawyer P, Aban I, Sims RV, Ahmed A.

Understanding the reasons for the underuse of pneumococcal vaccination by community-dwelling older African Americans. J Am Geriatr Soc. 2010 Dec;58(12):2323-8. doi: 10.1111/j.1532-5415.2010.03181.x.

Kaplan A, Arsenault P, Aw B, Brown V, Fox G, Grossman R, Jadavji T, Laferrière C, Levitz S, Loeb M, Mclvor A, Mody CH, Poulin Y, Shapiro M, Tessier D, Théorêt F, Weiss K, Yaremko J, Zhanel G. Vaccine 
strategies for prevention of community-acquired pneumonia in Canada: Who would benefit most from pneumococcal immunization? Can Fam Physician. 2019 Sep;65(9):625-633

Kim SH, Bae IK, Park D, Lee K, Kim NY, Song SA, Kim HR, Jeon GW, Urm SH, Shin JH. Serotype Distribution and Antimicrobial Resistance of Streptococcus pneumoniae Isolates Causing Invasive and Noninvasive Pneumococcal Diseases in Korea from 2008 to 2014. Biomed Res Int. 2016;2016:6950482. doi: $10.1155 / 2016 / 6950482$.

Kislaya I, Rodrigues AP, Sousa-Uva M, Gómez V, Gonçalves P, Froes F, Nunes B. Indirect effect of 7-valent and 13-valent pneumococcal conjugated vaccines on pneumococcal pneumonia hospitalizations in elderly. PLoS One. 2019 Jan 16;14(1):e0209428. doi: 10.1371/journal.pone.0209428

Kumar N, Sharma S, Barua S, Tripathi BN, Rouse BT. Virological and Immunological Outcomes of Coinfections Clin Microbiol Rev. 2018 Oct; 31(4): e00111-17. doi: 10.1128/CMR.00111-17

Kuo K, Chen U, Yang C, Wu Y, Gau C. The Cost-Effectiveness of Pneumococcal Vaccination in Taiwan Older Adults. Value in Health J. 2018, 21 Suppl 7, S67. DOI:https://doi.org/10.1016/j.jval.2018.07.504

Lang J, Yang N, Deng J, Liu K, Yang P, Zhang G, Jiang C. Inhibition of SARS pseudovirus cell entry by lactoferrin binding to heparan sulfate proteoglycans. PLoS One. 2011;6(8):e23710. doi:

10.1371/journal.pone.0023710. Epub 2011 Aug 22.

Lehocka L, Masarykova L, Olearova A,Koscova D. 2016. Analysis of Influenza Vaccination Effectiveness In General Practitioner. Value in Health J. 19(7), PA420, DOI:https://doi.org/10.1016/j.jval.2016.09.424

Ljungström LR, Jacobsson G, Claesson BEB, Andersson R, Enroth H. Respiratory viral infections are underdiagnosed in patients with suspected sepsis. Eur J Clin Microbiol Infect Dis. 2017 Oct;36(10):17671776. doi: 10.1007/s10096-017-2990-z.

Louisiana. 2020. Louisiana Government Department of Health, Health Data.

https://healthdata.dhh.la.gov/ and Coronavirus data http://ldh.la.gov/Coronavirus/Accessed 4 April 2020.

Natsuki, K, Kataoka Y, Goto R, Maeno T, Yokoya S, Umeyama S, Takahasi S, Maeno T. Factors associated with influenza vaccination in Japanese elderly outpatients. Infection, Disease \& Health, 2019, 24(4), 212 $-221$

Kumar M, Fukuda T, Stankus AP, DiBonaventura M. Influenza Vaccination In Japan Among The General Population And High-Risk Groups. Value Health. 2014 Nov;17(7):A804. doi: 10.1016/j.jval.2014.08.509.

Lavoignet CE, Le Borgne P, Chabrier S, Bidoire J, Slimani H, Chevrolet-Lavoignet J, Lefebvre F, Jebri R, Sengler L, Bilbault $P$ and the CREMS network. White blood cell count and eosinopenia as valuable tools for the diagnosis of bacterial infections in the ED. Eur J Clin Microbiol Infect Dis. 2019 Aug;38(8):15231532. doi: 10.1007/s10096-019-03583-2.

Lexau, CA, Lynfield, R, Danila, R et al. Changing epidemiology of invasive pneumococcal disease among older adults in the era of pediatric pneumococcal conjugate vaccine. JAMA. 2005; 294: 2043-2051 
Qilin Li, Xiuli Ding, Geqing Xia, Zhi Geng, Fenghua Chen, Lin Wang, Zheng Wang. A simple laboratory parameter facilitates early identification of COVID-19 patients. MedRXiv. doi:

https://doi.org/10.1101/2020.02.13.20022830

Linchevski I, Klement E, Nir-Paz R. Mycoplasma pneumoniae vaccine protective efficacy and adverse reactions--Systematic review and meta-analysis. Vaccine. 2009 Apr 21;27(18):2437-46. doi: 10.1016/j.vaccine.2009.01.135.

Liu GS, Li H, Zhao SC, Lu RJ, Niu PH, Tan WJ. Viral and Bacterial Etiology of Acute Febrile Respiratory Syndrome among Patients in Qinghai, China. Biomed Environ Sci. 2019 Jun;32(6):438-445. doi: 10.3967/bes2019.058.

Liu S, Xu E, Liu Y, Xu Y, Wang J, Du J, Zhang X, Che X, Gu W. Factors associated with pneumococcal vaccination among an urban elderly population in China. Hum Vaccin Immunother. 2014;10(10):2994-9. doi: 10.4161/21645515.2014.972155.

Lu PJ, O'Halloran A, Williams WW, Lindley MC, Farrall S, Bridges CB. Racial and Ethnic Disparities in Vaccination Coverage Among Adult Populations in the U.S. Am J Prev Med. 2015 Dec;49(6 Suppl 4):S41225. doi: 10.1016/j.amepre.2015.03.005.

Madar R, Strakova J, Baska T, Kavcova E, Straka S. Pneumococcal vaccination--current situation and perspectives. BratisI Lek Listy. 2005;106(3):119-22.

Mahamat A, Daurès JP, de Wzieres B. Additive preventive effect of influenza and pneumococcal vaccines in the elderly: results of a large cohort study. Hum Vaccin Immunother. 2013 Jan;9(1):128-35. doi: 10.4161/hv.22550.

Maraki S, Mavromanolaki VE, Stafylaki D, Hamilos G, Samonis G. The Evolving Epidemiology of Serotype Distribution and Antimicrobial Resistance of Streptococcus pneumoniae Strains Isolated from Adults in Crete, Greece, 2009-2016. Infect Chemother. 2018 Dec; 50(4): 328-339. Published online 2018 Dec 14. doi: $10.3947 /$ ic.2018.50.4.328

McNamee LA, Harmsen AG. Both Influenza-Induced Neutrophil Dysfunction and NeutrophilIndependent Mechanisms Contribute to Increased Susceptibility to a Secondary Streptococcus pneumoniae Infection. Infect Immun. 2006 Dec; 74(12): 6707-6721. doi: 10.1128/IAI.00789-06

Mereckiene, Jolita. European Centre for Disease Prevention and Control. Seasonal influenza vaccination in Europe. Vaccination recommendations and coverage rates in the EU member states for eight influenza seasons: 2007-2008 to 2014-2015. 2017.

https://ecdc.europa.eu/sites/portal/files/documents/influenza-vaccination-2007\%E2\%80\%932008-to2014\%E2\%80\%932015.pdf.

MDHHS. 2020. Michigan Department of Health and Human Services County Immunization Report Card. https://www.michigan.gov/mdhhs/0,5885,7-339-73971 49114914 68361-321114--,00.html Accessed 2 April 2020.

Milk Consumption: https://en.wikipedia.org/wiki/List_of_countries_by_milk_consumption_per_capita Accessed 4 May 2020. 
Aaron Miller, Mac Josh Reandelar, Kimberly Fasciglione, Violeta Roumenova, Yan Li, and Gonzalo H. Otazu* Correlation between universal BCG vaccination policy and reduced morbidity and mortality for COVID-19: an epidemiological study. medRxiv preprint doi: https://doi.org/10.1101/2020.03.24.20042937 Accessed 8 April 2020.

Morens DM, Taubenberger JK, Fauci AS. Predominant role of bacterial pneumonia as a cause of death in pandemic influenza: Implications for pandemic influenza preparedness. J Infect Dis2008; 198: 962-70.

Naito T, Suzuki M, Fujibayashi K, Kanazawa A, Takahashi H, Yokokawa H, Watanabe A. The estimated impact of the 5-year national vaccination program on the trend of 23-valent pneumococcal polysaccharide vaccine vaccination rates in the elderly in Japan, 2009-2018. J Infect Chemother. 2020 Apr;26(4):407-410. doi: 10.1016/j.jiac.2019.12.011.

Nix EB, Hawdon N, Gravelle S, Biman B, Brigden M, Malik S, McCready W, Ferroni G, Ulanova M. Risk of invasive Haemophilus influenzae type $b(\mathrm{Hib})$ disease in adults with secondary immunodeficiency in the post-Hib vaccine era. Clin Vaccine Immunol. 2012 May;19(5):766-71. doi: 10.1128/CVI.05675-11.

Park DC, Kim SH, Yong D, Suh IB, Kim YR, Yi J, Song W, Song SA, Moon HW, Lee HK, Park KU, Kim S, Jeong SH, Lee J, Jeong J, Kim YK, Lee M, Cho J, Kim JW, Shin KS, Hwang SH, Chung JW, Woo HI, Lee CH, Ryoo N, Chang CL, Kim HS, Kim J, Shin JH, Kim SH, Lee MK, Lee SG, Jang SJ, Lee K, Suh H, Sohn YH, Kwon MJ, Lee HJ, Hong KH, Woo KS, Park CM, Shin JH. Serotype Distribution and Antimicrobial Resistance of Invasive and Noninvasive Streptococcus pneumoniae Isolates in Korea between 2014 and 2016. Ann Lab Med. 2019 Nov;39(6):537-544. doi: 10.3343/alm.2019.39.6.537.

Pletz MW, Ewig S, Rohde G, Schuette H, Rupp J, Welte T, Suttorp N, Forstner C; CAPNETZ Study Group. Impact of pneumococcal vaccination in children on serotype distribution in adult community-acquired pneumonia using the serotype-specific multiplex urinary antigen detection assay. Vaccine. $2016 \mathrm{Apr}$ 29;34(20):2342-8. doi: 10.1016/j.vaccine.2016.03.052

Porcheddu R, Serra C, Kelvin D, Kelvin N, Rubino S. Similarity in Case Fatality Rates (CFR) of COVID19/SARS-COV-2 in Italy and China. J Infect Dev Ctries. 2020 Feb 29;14(2):125-128. doi: 10.3855/jidc.12600.

Reghunathan R, Jayapal M, Hsu LY, Chng HH, Tai D, Leung BP, Melendez AJ. Expression profile of immune response genes in patients with Severe Acute Respiratory Syndrome. BMC Immunol. 2005 Jan $18 ; 6: 2$.

Richter L, Schmid D, Kanitz EE, Zwazl I, Pöllabauer E, Jasinska J, Burgmann H, Kundi M, Wiedermann U. Invasive pneumococcal diseases in children and adults before and after introduction of the 10-valent pneumococcal conjugate vaccine into the Austrian national immunization program. PLoS One. 2019 Jan 10;14(1):e0210081. doi: 10.1371/journal.pone.0210081.

Root-Bernstein RS, Podufaly A., Aimone F. Antigenic Complementarity between Influenza A Virus and Haemophilus Influenzae may Drive Lethal Co-Infection Such As That Seen In 1918-19. J Virol Antivir Res 2013, 2:1 doi: 10.4172/2324-8955.1000104.

https://www.umaryland.edu/news/archived-news/april-2020/can-an-oral-polio-vaccine-stop-covid19.php 
Natsumi Shibata, Shinya Kimura, Takahiro Hoshino, and Hisashi Urushihara. Influenza vaccination effectiveness for people aged under 65 years in Japan, 2013/2014 season: application of a doubly robust method to a large-scale, real-world dataset. BMC Infect Dis. 2019; 19: 586. doi: 10.1186/s12879-0194186-x

Shokouhi S, Alavi Darazam I, Kardan G. Adult Immunization Among Health Care Personnel and Target Groups in Iran, Arch Clin Infect Dis. 2015 ; 10(1):e24714. doi: 10.5812/archcid.24714.

Shope RE (1931) Swine influenza: I. Experimental transmission and pathology. J Exp Med 54: 349-359.

Sings HL. Pneumococcal conjugate vaccine use in adults - Addressing an unmet medical need for nonbacteremic pneumococcal pneumonia. Vaccine. 2017 Sep 25;35(40):5406-5417. doi:

10.1016/j.vaccine.2017.05.075.

Song JY, Cheong HJ, Heo JY, Noh JY, Seo YB, Kim IS, Choi WS, Kim WJ. Outpatient-based pneumococcal vaccine campaign and survey of perceptions about pneumococcal vaccination in patients and doctors. Yonsei Med J. 2013 Mar 1;54(2):469-75. doi: 10.3349/ymj.2013.54.2.469.

Statista. 30 March 2020. Coronavirus (COVID-19) cases in Italy as of March 30, 2020, by region https://www.statista.com/statistics/1099375/coronavirus-cases-by-region-in-italy/accessed 31 March 2020.

Storhaug CL, Fosse SK, Fadnes LT. Country, regional, and global estimates for lactose malabsorption in adults: a systematic review and meta-analysis. Lancet Gastroenterol Hepatol. 2017 Oct;2(10):738-746. doi: 10.1016/S2468-1253(17)30154-1.

Sun H, Jenssen H. 2012. Milk Derived Peptides with Immune Stimulating Antiviral Properties, Milk Protein, Walter L. Hurley, IntechOpen, DOI: 10.5772/50158. Available from:

https://www.intechopen.com/books/milk-protein/milk-derived-peptides-with-immune-stimulatingantiviral-properties

Takeda H, Sato C, Bin C, Nishidzuka M, Watanabe M, Yamamoto T, Suzuki H, Oishi K, Tsuchida F. Changes in the Pneumococcal Vaccine Serotypes in Adult Noninvasive Pneumonia after the Introduction of Pneumococcal Conjugate Vaccination for Children. J Glob Infect Dis. 2019 Jan-Mar;11(1):30-35. doi: 10.4103/jgid.jgid_167_17.

Theidel U, Kuhlmann A, Braem A. Pneumococcal vaccination rates in adults in Germany: an analysis of statutory health insurance data on more than 850,000 individuals. Deutsches Ärzteblatt international, 2013; 110(44), 743-750.

Tiley KS, White JM, Andrews N, Ramsay M, Edelstein M. Inequalities in childhood vaccination timing and completion in London. Vaccine. 2018 Oct 29;36(45):6726-6735. doi: 10.1016/j.vaccine.2018.09.032.

Toleman MS, Herbert K, McCarthy N, Church DN. Vaccination of chemotherapy patients--effect of guideline implementation. Support Care Cancer. 2016 May;24(5):2317-2321. doi: 10.1007/s00520-0153037-6. 
Tozzi AE, Piga S, Corchia C, Di Lallo D, Carnielli V, Chiandotto V, Fertz MC, Miniaci S, Rusconi F, Cuttini M. Timeliness of routine immunization in a population-based Italian cohort of very preterm infants: results of the ACTION follow-up project. Vaccine. 2014 Feb 7;32(7):793-9. doi: 10.1016/j.vaccine.2013.12.044.

Vestjens SMT, Sanders EAM, Vlaminckx BJ, de Melker HE, van der Ende A, Knol MJ. Twelve years of pneumococcal conjugate vaccination in the Netherlands: Impact on incidence and clinical outcomes of invasive pneumococcal disease. Vaccine. 2019 Oct 8;37(43):6558-6565. doi:

10.1016/j.vaccine.2019.08.025

Wang L, He W, Yu X, Hu D, Bao M, Liu H, Zhou J, Jiang H. Coronavirus Disease 2019 in elderly patients: characteristics and prognostic factors based on 4-week follow-up. J Infect. 2020 Mar 30. pii: S01634453(20)30146-8. doi: 10.1016/j.jinf.2020.03.019

Wateska AR, Nowalk MP, Lin CJ, Harrison LH, Schaffner W, Zimmerman RK, Smith KJ. Pneumococcal Vaccination in Adults Aged $\geq 65$ Years: Cost-Effectiveness and Health Impact in U.S. Populations. Am J Prev Med. 2020 Apr;58(4):487-495. doi: 10.1016/j.amepre.2019.10.022.

Westall, F. C. and Root Bernstein, R. S. "The Cause and Prevention of Post Infectious and Post Vaccinal Encephalopathies in Light of a New Theory of Autoimmunity," Lancet 2 August 1986, 251252.

Wiese AD, Griffin MR, Grijalva CG. Impact of pneumococcal conjugate vaccines on hospitalizations for pneumonia in the United States. Expert Rev Vaccines. 2019 Apr;18(4):327-341. doi:

10.1080/14760584.2019.1582337.

Williams WW, Lu PJ, O'Halloran A, Kim DK, Grohskopf LA, Pilishvili T, Skoff TH, Nelson NP, Harpaz R, Markowitz LE, Rodriguez-Lainz A, Bridges CB; Centers for Disease Control and Prevention (CDC). Surveillance of Vaccination Coverage Among Adult Populations - United States, 2014. MMWR Surveill Summ. 2016 Feb 5;65(1):1-36. doi: 10.15585/mmwr.ss6501a1.

WHO. World Health Organization, Immunization, vaccines and biologicals. https://www.who.int/immunization/monitoring surveillance/data/en/ Accessed 30 March 2020.

Worldometer. https://www.worldometers.info/coronavirus/\#countries

Xia W, Shao J, Guo Y, Peng X, Li Z, Hu D. Clinical and CT features in pediatric patients with COVID-19 infection: Different points from adults. Pediatr Pulmonol. 2020 Mar 5. doi: 10.1002/ppul.24718.

Yang L, Chan KP, Wong CM, Chiu SSS, Magalhaes RJS, Thach TQ, Peiris JSM, Clements ACA, Hu W. Comparison of influenza disease burden in older populations of Hong Kong and Brisbane: the impact of influenza and pneumococcal vaccination. BMC Infect Dis. 2019 Feb 14;19(1):162. doi: 10.1186/s12879019-3735-7.

Yang TU, Song JY, Noh JY, Cheong HJ, Kim WJ. Influenza and Pneumococcal Vaccine Coverage Rates among Patients Admitted to a Teaching Hospital in South Korea. Infect Chemother. 2015 Mar;47(1):418. doi: 10.3947/ic.2015.47.1.41

Yang TU, Kim E, Park YJ, Kim D, Kwon YH, Shin JK, Park O. Successful introduction of an underutilized elderly pneumococcal vaccine in a national immunization program by integrating the pre-existing public health infrastructure. Vaccine. 2016 Mar 18;34(13):1623-1629. doi: 10.1016/j.vaccine.2016.01.043. 
22

Zahariadis G, Gooley TA, Ryall P, Hutchinson C, Latchford MI, Fearon MA, Jamieson FB, Richardson S, Kuschak T, Mederski B. Risk of ruling out severe acute respiratory syndrome by ruling in another diagnosis: variable incidence of atypical bacteria coinfection based on diagnostic assays. Can Respir J. 2006 Jan-Feb;13(1):17-22.

Zhang D, Petigara T, Yang X. Clinical and economic burden of pneumococcal disease in US adults aged 19-64 years with chronic or immunocompromising diseases: an observational database study. BMC Infect Dis. 2018 Aug 29;18(1):436. doi: 10.1186/s12879-018-3326-z.

Zhang JJ, Dong X, Cao YY, Yuan YD, Yang YB, Yan YQ, Akdis CA, Gao YD. Clinical characteristics of 140 patients infected with SARS-CoV-2 in Wuhan, China. Allergy. 2020 Feb 19. doi: 10.1111/all.14238. 